\title{
Association of Uric Acid Level and Body Mass Index in Type 2 Diabetes Mellitus Patients
}

\author{
Maya savira $^{1^{*}}$, Rusdiana $^{2}$, Gilbert $^{3}$ \\ ${ }^{I}$ Departement of Physiology,Faculty of Medical Universitas Sumatera Utara, North Sumatera \\ Medan,Indonesia \\ ${ }^{2}$ Departement of Biochemistry ,Faculty of Medical Universitas Sumatera Utara, North Sumatera Medan, \\ Indonesia \\ ${ }^{3}$ Student,Faculty of Medical Universitas Sumatera Utara, North Sumatera Medan, Indonesia
}

\begin{abstract}
Body Mass Index (BMI) or formerly called Quetelet Index is the measurement for scoring nutrient state in adults by using body weight (in kilogram) and body height (in metre). Obesity and overweight are defined as an abnormality of fat accumulation that can damage our health. Uric acid is a substance that is formed when the breaking process of purine occur. Hyperuricemia are condition that are closely related with gout. Uric acid level increased significantly towards those having obesity. It is also concluded that obesity was the usual cause in patients with recurrent gout attack. Strong relation has been found between high BMI with gout arthritis occurance. This research is a descriptive analytic research with cross sectional design included 50 diabetic subjects aged over 40 years old. Subjects picked by consecutive sampling then we examined the weight, height, waist size, blood pressure and laboratory tests for fasting blood sugar and serum uric acid level. With statistical analysis using chi square we found that there was no significant association between BMI and serum uric acid level in type 2 diabetes mellitus patients ( $p>0.005)$.
\end{abstract}

Keywords: Body Mass Index, Diabetes Mellitus, Type 2 Diabetes Mellitus

\begin{abstract}
Abstrak. Body Mass Index (BMI) atau sebelumnya disebut Quetelet Index adalah pengukuran untuk menilai keadaan gizi pada orang dewasa dengan menggunakan berat badan (dalam kilogram) dan tinggi badan (dalam meter). Obesitas dan kegemukan didefinisikan sebagai kelainan penumpukan lemak yang dapat merusak kesehatan kita. Asam urat adalah zat yang terbentuk ketika proses pemecahan purin terjadi. Hiperurisemia adalah kondisi yang berkaitan erat dengan asam urat. Tingkat asam urat meningkat secara signifikan terhadap mereka yang mengalami obesitas. Juga disimpulkan bahwa obesitas adalah penyebab umum pada pasien dengan
\end{abstract}

\footnotetext{
*Corresponding author at: Departement of Physiology, Faculty of Medical USU, Medan, Indonesia

E-mail address: dr.mayasavira@yahoo.co.id
} 
serangan gout berulang. Hubungan yang kuat telah ditemukan antara BMI tinggi dengan kejadian artritis gout. Penelitian ini merupakan penelitian deskriptif analitik dengan desain cross sectional yang meliputi 50 subjek diabetes berusia di atas 40 tahun. Subjek diambil secara consecutive sampling kemudian kami memeriksa berat, tinggi, ukuran pinggang, tekanan darah dan tes laboratorium untuk kadar gula darah puasa dan serum asam urat serum. Dengan analisis statistik menggunakan chi square, kami menemukan bahwa tidak ada hubungan yang signifikan antara BMI dan kadar asam urat serum pada pasien diabetes melitus tipe 2 ( $p>0,005)$.

Kata Kunci: Body Mass Index, Diabetes Mellitus, Type 2 Diabetes Mellitus Received 5 February 2020 | Revised 20 February 2020| Accepted 20 March 2020

\section{Introduction}

Body Mass Index (BMI) has been used to chategorize people as underweight, normoweight and obese. An individu determined as obese based on Body Mass Index (BMI) it is a simple index of weight-height relationship calculated as weight in $(\mathrm{kg})$ divided by height in (m) squared. One is categorized as obese I when the BMI 25-29,9 $\mathrm{kg} / \mathrm{m}^{2}$ and obese II when the BMI $>30 \mathrm{~kg} / \mathrm{m}^{2}$ [1]. Obesity can occur when there is an imbalance between calory intake and bodily use of those calories and is more likely when there is decreased physique activity [2]. In 2004, on estimated $13 \%$ of adults worldwide (11\% of men and $15 \%$ of women) were obese [3]. An estimated $39 \%$ of adults aged $\geq 18$ years old ( $38 \%$ of men and $40 \%$ of women) are overweight [3].

In Indonesia in 2013 from all of the population, estimated $8.2 \%$ of women aged $\geq 18$ years old were obese, and $24.2 \%$ were overweight [4]. The lowest obesity prevalence in is located in East Nusa Tenggara province (6.2\%) and the highest is in North Sulawesi (24.0\%) [4]. Another study determined the prevalence of obesity in North Sumatra province during 2013, was $27 \%$ compared to average of $20 \%$ [5].

Uric acid is a substance that is formed when the breaking process of purine occur. Most uric acid will be dissolved in the blood an go towards kidneys and will exit through urine. If our body produces uric acid in large amount or cannot be exit in an enough amount, then the uric acid level in our blood will increase or usually hyperuricemia [6]. Hyperuricemia or increased of serum uric acid level above normal are condition that are closely related with gout where monosodium urate crystals are deposited in joint and soft tissue [7]. According to research data at Dr Hasan Sadikin Hospital in 2012, from all gout patients, 12.22 percent were obese, 15.70 percent were having infarc myocard, 25.39 percent were having diabetes mellitus, 42.73 percent were having hypertension, and 53.08 percent were having chronic kidney disease [8]. Based on previous research 
to know if an increased uric acid level have occurred in children and teens having obesity, they found the result that uric acid level increased significantly towards those having obesity and could be used as one indicator of increased uric acid level in early teens [9]. Zhang and Rothenbacher in 2008 in their research that also analyzed the relation between BMI and frequency of gout attack, concluded that obesity was the usual cause in patients with recurrent gout attack [10].

According to the research by Sipayung et al. towards teenagers at SMP Swasta Manado in 2013, it can be concluded that there are no significant relations between obesity and increased level of uric acid [9]. Sara et al. in their research concluded that, the individuals with metabolic syndrome have higher uric acid level. The association of uric acid and metabolic syndrome components supports that it might be an additional components of metabolic syndrome [11]. In other previous studies, an association between serum uric levels and metabolic syndrome has been reported [12]. Therefore this study aimed to analyze the association uric acid level and body mass index in type 2 diabetes mellitus patients.

\section{Methods}

This research is analytic descriptive research method with cross-sectional approach. Research populations were the patients visited public health in Medan Selayang. Research samples are the patients visited public health in Medan Selayang in accordance the inclusion and exclusion criteria. The samples are chosen with consecutive-sampling way. Research's inclusion criteria are: aged over 40 years old. (1) and patients that are ready as research sample by signing agreement sheet after being explained with informed consent. (2) Research's exclusion criteria are patients are being treated with cancer therapy and diuretics. This research was approved by Health Research Ethical Committee, Medical Faculty of Universitas Sumatera Utara/ H. Adam Malik General Hospital.

Method of data colletion using primary data that are directly obtained from physic examination incuding body weight and height, waist size and laboratorium tests including Fasting blood sugar, Hba1C and serum uric acid level from the patients. All statistical analyses were carried out using chi square. P-value $<0.05$ was considered as significant. 


\section{Results and Discussions}

The characteristic of the subjects of this research are shown in Table 1. In this research the the average age of the samples is 59.50 years old, BMI is $26.11 \mathrm{~kg} / \mathrm{m}^{2}$, waist size is 140.56, Fasting Blood Sugar is $199.18 \mathrm{mg} / \mathrm{dl}$, Hba1C is $10.73 \%$ and uric acid is 6.49 $\mathrm{mg} / \mathrm{dl}$.

Table 1. Baseline characteristics of the 40 samples

\begin{tabular}{llll}
\hline & $\mathrm{N}$ & Mean \pm SD & $\mathrm{P}$ \\
\hline Age & 50 & $59.50 \pm 8.62$ & \\
BMI & 50 & $26.11 \pm 3.56$ & \\
Waist size & 50 & $140.56 \pm 189.30$ & \\
FBS & 50 & $199.18 \pm 77.63$ & \\
Hba1C & 50 & $10.73 \pm 13.70$ & \\
Uric acid & 50 & $6.49 \pm 1.70$ & $>0.005$ \\
\hline
\end{tabular}

This study aimed to analyze the association uric acid level and body mass index in type 2 diabetes mellitus patients, so we used the statistical analysis with chi square and found that there was no significant association between uric acid level and body mass index in type 2 diabetes mellitus patients ( $\mathrm{p}>0.005)$.

The previous studies report that obesity has long been recognized as an associated factor with a variety of adverse health consequences; chiefly among them are diabetes, hypertension, dyslipidaemia, increased cardiovascular events, and elevated serum uric acid [14].

Previous published paper indicated that weight loss was thought to be an effective non-medical strategy for serum uric acid level reduction in the Japanese population [15] contrary to our research that found no significant association between uric acid and body mass index it might be because body mass index is not the only and major factor that influence uric acid level there are many other factors such as high consumed of food that contains high level of purine, low excretion, high synthesis or both [13].

\section{Conclusions}

The cross sectional study concluded that there was no significant association between uric acid level and body mass index in type 2 diabetes mellitus patients ( $p>0.05$ ), but however uric acid is a substance that is formed by metabolic proccess. Body weight which is one of two main factors that determine BMI can greatly affect the metabolic proccess so we have to keep in our mind that however the type $2 \mathrm{DM}$ patients still have to maintain the BMI to keep the uric acid level remain within normal limits range. 


\section{Acknowledgment}

The authors gratefully acknowledge that the present research is supported by Ministry of Research and Technology and Higher Education Republic Indonesia. The support is under the research grant NON PNHB USU of year 2019.

\section{References}

[1] M. Hein, J. P. Lanquart, P. Hubain, and G. Loas, "Risk of resistant hypertension associated with restless legs syndrome and periodic limb movements during sleep: a study on 673 treated hypertensive individuals". Sleep Medicine, 2019.

[2] T. B. Chaston and J. B. Dixon, "Factors associated with percent change in visceral versus subcutaneous abdominal fat during weight loss: findings from a systematic review”. International Journal of Obesity, vol. 32, no. 4, pp. 619-628, 2008.

[3] I. Lissau, M. D. Overpeck, W. J. Ruan, P. Due, B. E. Holstein, and M. L. Hediger, "Body mass index and overweight in adolescents in 13 European countries, Israel, and the United States". Archives of Pediatrics \& Adolescent Medicine, vol. 158, no. 1, pp. 27-33, 2004.

[4] Kementerian Kesehatan. Riset Kesehatan Dasar (Riskesdas). Kemenkes RI. 2013.

[5] D. Lindarto and S. S. Shierly, "Neck circumference in overweight/obese subjects who visited the binjai supermall in Indonesia". Macedonian Journal of Medical Sciences, vol. 4, no. 3, p. 319, 2016.

[6] T. Y. Chang, K. H. Huang, C. S. Liu, R. H. Shie, K. P. Chao, W. H. Hsu, and B. Y. Bao, "Exposure to volatile organic compounds and kidney dysfunction in thin film transistor liquid crystal display (TFT-LCD) workers". Journal of Hazardous Materials, vol. 178, no. 1-3: pp. 934-940, 2010.

[7] S. Ottaviani, T. Bardin, and P. Richette, "Usefulness of ultrasonography for gout". Joint Bone Spine, vol. 79, no. 5, pp. 441-445, 2012.

[8] W. R. Limanjaya, R. G. Wachjudi, and H. Tansah, "Comorbidities in patients with gout in rheumatology clinic Dr. Hasan Sadikin general hospital in 2012-2013”. Indonesian Journal of Rheumatology, vol. 8, no. 1.

[9] E. Z. Sipayung, "Hubungan Obesitas Dengan Peningkatan Asam Urat Pada Remaja Di Sekolah Menengah Pertama". e-CliniC, vol. 2, no. 1, 2014.

[10] Q. L. Zhang and D. Rothenbacher, "Prevalence of chronic kidney disease in population-based studies: systematic review". BMC Public Health, vol. 8, no. 1, p. 117, 2008.

[11] S. Nejatinamini, A. Ataie-Jafari, M. Qorbani, S. Nikoohemat, R. Kelishadi, H. Asayesh, and S. Hosseini, "Association between serum uric acid level and metabolic syndrome components". Journal of Diabetes \& Metabolic Disorders, vol. 14, no. 1, p. 70, 2015.

[12] T. W. Yoo, K. C. Sung, H. S. Shin, B. J. Kim, B. S. Kim, J. H. Kang, M. H. Lee, J. R. Park, H. Kim, E. J. Rhee, and W. Y. Lee, "Relationship between serum uric acid concentration and insulin resistance and metabolic syndrome". Circulation Journal, vol. 69, no. 8, pp. 928-933, 2005.

[13] J. H. Chen, S. Y. Chuang, H. J. Chen, W. T. Yeh, and W. H. Pan, "Serum uric acid level as an independent risk factor for all-cause, cardiovascular, and ischemic 
stroke mortality: a Chinese cohort study". Arthritis Care \& Research. Vol. 61, no. 2, pp. 225-232, 2009.

[14] D. G. Carey, A. B. Jenkins, L. V. Campbell, J. Freund, and D. J. Chisholm, "Abdominal fat and insulin resistance in normal and overweight women: direct measurements reveal a strong relationship in subjects at both low and high risk of NIDDM”. Diabetes, vol. 45, no. 5, pp. 633-638, 1996.

[15] N. Ishizaka, Y. Ishizaka, A. Toda, M. Tani, K. Koike, M. Yamakado, and R. Nagai, "Changes in waist circumference and body mass index in relation to changes in serum uric acid in Japanese individuals". The Journal of Rheumatology, vol. 37, no. 2, pp. 410-416, 2010. 